There is a saying in contemporary Poland that "everything is political." Accepting the truth of this dictum, this reviewer found a very poignant note in Walicki's discussion of the "superfluous man." He quotes Belinsky, Turgenev, and Herzen's observation that in the 1840s Russian intellectuals of gentry origin were aimless wanderers, strangers at home, foreigners abroad-an apt description of Poland's young intellectuals since the end of the Thaw.

AlFred BLOCH

State University of New York, Nerv Palts

\title{
YEARS OF THE GOLDEN COCKEREL: THE LAST ROMANOV TSARS, 1814-1917. By Sidney Harcave. New York: The Macmillan Co. London: Collier-Macmillan Ltd., 1968. x, 515 pp. \$12.50.
}

While the New Left is occasionally patterning itself after the Russian revolutionaries of the nineteenth century, the Establishment seems enamored with the Russian autocracy. For the long-range perspective we have Ronald Hingley's work, The Tsars: 1533-1917. For slow-motion detail there is the sentimental documentary of Nicholas and Alexandra by Robert Massie. Professor Harcave now has given us an intermediary volume covering the last five tsars. He treats his subject in the spirit of allegory, taking his title from Pushkin's tale, subsequently made into an opera by Rimsky-Korsakov, about the Golden Cockerel and the mythical tsar Dadon, who, after having reached great magnificence, neglected his duties and came to grief. The tsars from Alexander I to Nicholas II, Harcave pleads, were like Dadon-rulers of exalted power who did not live up to their promise.

The allegory has shaped this book in a variety of ways. It begins not with the accession of Alexander I but with the "zenith of Romanov success" in 1814, when the tsar, "second in renown to none," like Dadon, rode into Paris at the head of the Allied forces, a gracious and high-minded victor. Eleven years after his triumphal entry into Paris, Alexander was in decline and the country was stagnating, except for the preparations of the Decembrists. The book ends with the murder of Nicholas II and his family in the cellar of the Ipatiev house in Ekaterinoslav. Down to the end of the Romanovs (and to the present, too, one might argue) each new regime passed through the cycle of a strong start and a disastrous end, as if under a curse. In the ascending phase the country was moving forward, confidence ran high, tranquillity prevailed. Then came the descent into ruin: the Crimean War, the assassination of Alexander II in 1881, the revolutions of 1905 and 1917. The only exception was the reign of Alexander III, who died at a moment of relative stability in his country's fortunes. In Harcave's telling it became largely the prologue to the next regime.

The symmetrical zigzag of imperial fortunes as laid out in this tale poses certain problems of chronology and historical analysis. The tsars' successes and failures were, in fact, not as neatly separated as they are in Harcave's chapters. Events belonging together in time had to be separated to fit the pattern-a practice that tends to impede historical understanding. There is indeed much truth to the pattern, and that needs to be stressed. The arrangement also gives the book a pleasing aesthetic quality. At times, however, the effect is one of oversimplification. Besides, the intrusion of allegory seems somewhat incongruous for a historian whose stated creed is to let facts speak for themselves.

Harcave's facts bespeak a standard historical approach. By necessity a history 
of the last Romanov tsars is also a history of Russia in those years. This book may be profitably read, especially by newcomers to the field, as a stylized chronicle of Russian history centered on the imperial family and the court. As history it stops somewhat short at points where sophisticated readers might expect some fascinating insights. We learn all too little about the inner life and psychology of the autocrats. What better opportunity could there be of observing exalted men under extreme stress or of gaining a deeper understanding of the unspeakable tragedies of supreme -and mostly unwanted-responsibility in a country so difficult to govern as the Russian Empire?

Even commonplace historical subjects are treated casually or passed over. Reading this volume one keeps wondering about the politics of autocracy. How did the tsars effect basic changes such as the emancipation of the serfs? How did they cope with the ceaseless wheeling and dealing that took place behind the bland façade of monolithic unity? Although the author devotes more than a third of his book to the reign of Nicholas II, he has little to say about one of its most crucial aspects, the pseudoconstitutional phase, 1905-14. He does so in the clichés of the time rather than in the light of more recent analysis. Nor do we learn much about the complex relationship between the tsar and Stolypin. The author seems unaware of the recent scholarly discussion over sociopolitical trends in Russia before 1914; he never even mentions the disturbances of July 1914.

Harcave implies in his conclusion that the collapse of the empire was caused by the incompetence of its rulers, especially the last one. Had Nicholas II "been endowed with administrative competence, with diplomatic prudence in the handling of affairs in the Far East, and with luck, he might have avoided that first fateful loss of footing-in the Revolution of 1905" (p. 480). If there had been no first revolution, there would have been no second revolution, and all would have been well for Russia and the world.

This book was obviously intended for the same common reader who has been so engrossed in the story of Nicholas and Alexandra. While lauding its combination of popular orientation and soundness of scholarship, scholars may yet deplore the lack of the subtler insights into the dynamics of Russian development available in current professional literature. Harcave's bibliography, incidentally, reflects the same orientation. In his eagerness to work from the sources he has paid little heed to recent monographic studies and reinterpretations of Russian developments.

THEODORE H. VON LAUE

Washington University, St. Louis

RUSSIA UNDER THE LAST TSAR. Edited by Theofanis George Stavrou. Minneapolis: University of Minnesota Press, 1969. viii, 265 pp. \$7.50, cloth. $\$ 2.45$, paper.

Graduate students cramming for comprehensive examinations are always on the lookout for shortcuts to that glib expertise they are expected to acquire, and Stavrou's little book will do quite nicely for the purpose. Most of these eight essays (originally lectures) will give the enterprising student enough material to enable him to sound as if he has read the authors at greater depth.

Three essays-Arthur Mendel's, Thomas Riha's, and Theodore Von Laue'sbear on the question of Russia's constitutional development: was tsarist Russia's progress toward Western, constitutional government interrupted by World War 